\title{
Coulisses
}

Revue de théâtre

5 | Hiver 1992

Varia

\section{La Machine infernale}

d'après J. Cocteau, mise en scène J.-R. Bouvret

T.U.F.C. et Jean-René Bouvret

\section{CpenEdition}

Journals

Édition électronique

URL : http://journals.openedition.org/coulisses/1706

DOI : 10.4000/coulisses. 1706

ISSN : 2546-9460

Éditeur

Presses universitaires de Franche-Comté

Édition imprimée

Date de publication : 1 janvier 1992

Pagination : 13-14

ISSN : 1150-594X

Référence électronique

T.U.F.C. et Jean-René Bouvret, «La Machine infernale », Coulisses [En ligne], 5 | Hiver 1992, mis en ligne le 04 juillet 2017, consulté le 23 octobre 2019. URL : http://journals.openedition.org/coulisses/1706 ; DOI : 10.4000/coulisses. 1706

Ce document a été généré automatiquement le 23 octobre 2019

Coulisses 


\section{La Machine infernale}

d'après J. Cocteau, mise en scène J.-R. Bouvret

T.U.F.C. et Jean-René Bouvret

\section{NOTE DE L'ÉDITEUR}

Production Espace Planoise-Manches à balais Korporation, octobre 1991

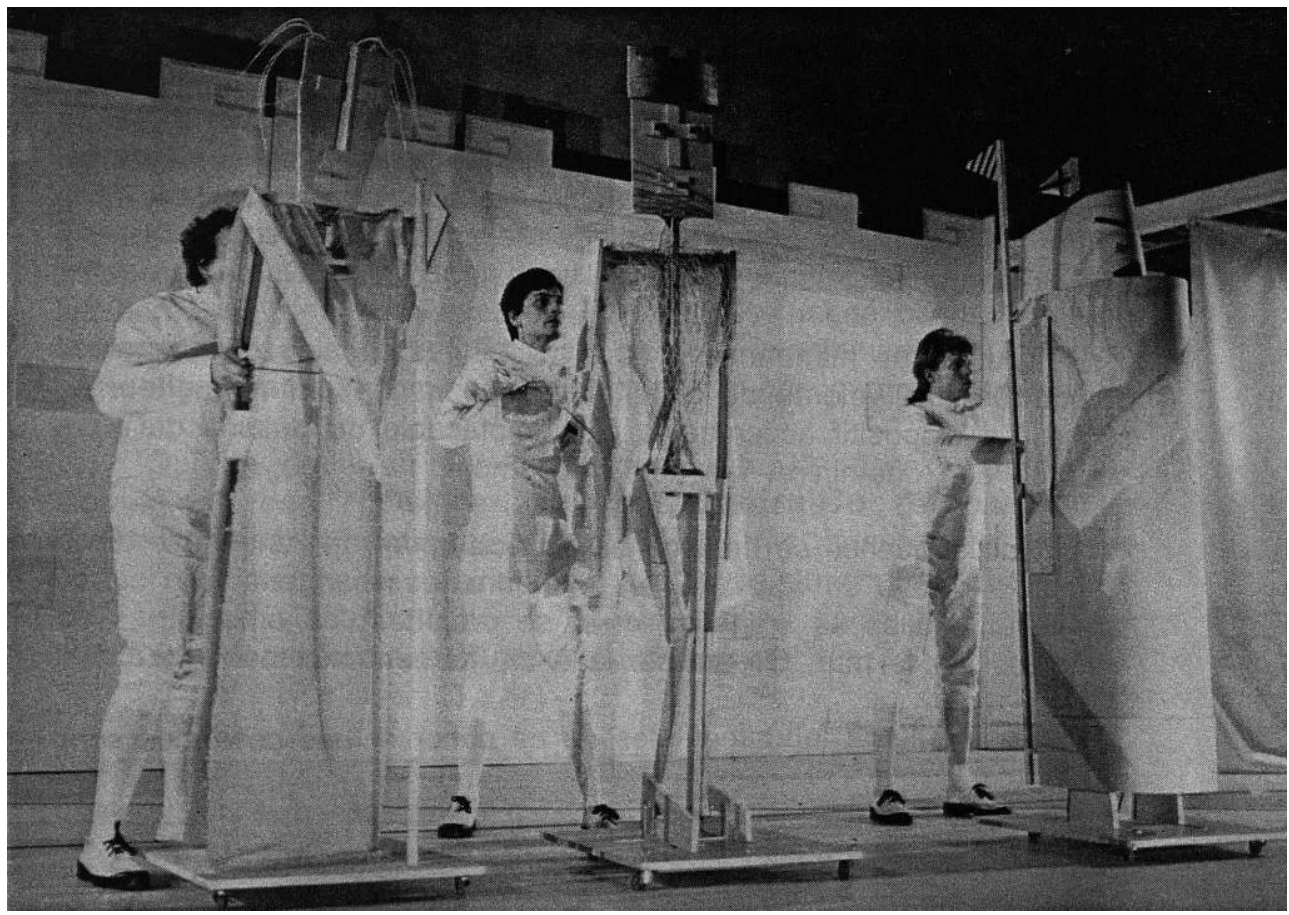

La Machine infernale.

Photo Yves Perton

T.U.F.C. : Pourquoi avoir choisi de monter cette pièce de Cocteau, La Machine infernale? 
2 J.-R. B. : Les grands mythes fondateurs de la société occidentale m'ont intéressé. Cocteau a entrepris de retrouver l'esprit de la tragédie grecque et a établi des correspondances entre elle et la lecture moderne. Il a adapté La Machine infernale en 1934, inspirée du mythe d'Æedipe et de son tragique destin qui le poursuit inexorablement.

\section{Impressions}

3 Le texte de Cocteau est écrit dans une langue quotidienne, banale. Jean-René Bouvret a pris le parti d'une mise en scène très construite inspirée par le mouvement Bauhaus, né en Allemagne, après la première guerre mondiale, et par le constructivisme russe. Cette scénographie mécanique accentue le côté inéluctable du destin d'đモdipe. La mise en scène tend des lignes horizontales croisées dans l'espace désignant ainsi les liens entre les protagonistes de l'action. Chaque personnage est caractérisé par une marionnette qui a sa géométrie propre. À titre d'exemple, les soldats sont représentés par des figures simples indiquant une fonction plutôt qu'une psychologie primaire. Jocaste se signale par des rondeurs plus féminines. đEdipe évoque une forme plus humaine avec davantage de possibilités, signifiant ainsi une personnalité plus complexe.

4 Toutes ces marionnettes sont actionnées à l'aide d'un manche et marquent la volonté de distanciation souhaitée par le metteur en scène. Le dispositif accentue le côté implacable du destin qui poursuit son chemin et qui doit s'accomplir.

5 Une séquence se détache plus précisément de l'ensemble du spectacle : celle du rêve. Ici, les marionnettes changent de dimension : elles se rapetissent et se projettent en ombres chinoises sur le mur. On assiste là à un moment très poétique.

6 Les couleurs fondamentales de ce décor et des costumes sont le blanc essentiellement avec des touches de noir et des ponctuations de rouge (écharpe de Jocaste, drap du rêve...).

7 La musique de Gilbert Henry, entêtante, obsédante, grinçante est celle d'un tango qui se dérègle et ajoute au malaise ressenti et à l'angoisse de ce que le spectateur pressent. Ce dernier assiste impuissant au déroulement d'un film dont il sait l'issue tragique. 